Book Review

\title{
(Not) Very Important People: Millennial Fantasies of Mobility in the Age of Excess
}

\author{
Susan Hopkins \\ USQ College, University of Southern Queensland, Australia; susan.hopkins@usq.edu.au
}

Submitted: 31 July 2021 | Accepted: 8 August 2021 | Published: 24 February 2022

\begin{abstract}
In her fascinating but frustrating new book, Very Important People: Status and Beauty in the Global Party Circuit, American sociologist, Ashley Mears (2020) offers both academic and mainstream readers a titillating, cross-over tour around the "cool" nightclub and party scene of the "global elite." It is perhaps not so much global, however, as American, in the sense of the heteropatriarchal, middle-aged, male, working rich of America (or more precisely of its financial capital New York), jetting into their traditional party hotspots of Miami, Saint-Tropez, or the French Riviera, to party with young women who are (indirectly) paid (in-kind) to pose with them. Whether intentional or unintentional, along the way Mears also offers a dark mirror to the fears and fantasies of a rather lost millennial generation, raised in a new media, image age, which has coupled fast and furious performative excess to old fashioned sexual objectification, in the guise of fun and empowerment for the beautiful people.
\end{abstract}

\section{Keywords}

beauty capital; ethnography; fashion models; global elites; hustle culture

\section{Issue}

This book review is part of the issue "New Narratives for New Consumers: Influencers and the Millennial and Centennial Generations" edited by Luis M. Romero-Rodríguez (Rey Juan Carlos University, Spain), Santiago Tejedor (Autonomous University of Barcelona, Spain) and Inmaculada Berlanga (International University of La Rioja, Spain).

(C) 2022 by the author(s); licensee Cogitatio (Lisbon, Portugal). This book review is licensed under a Creative Commons Attribution 4.0 International License (CC BY).

\section{Introduction}

If you were raised by television (not the internet), as part of the generation or demographic group widely known as " $X$," you might think you know something already about the glamourous "global party circuit," as you grew up, after all, watching postmodern television programs like Miami Vice or Lifestyles of the Rich and Famous. Perhaps you have seen the wonderful film Casino and think you know something already about the murky world of "whales"-or big spending high rollers-and the well-dressed women who float around them. In this assumption, reader, you would be wrong. Worse still, you might be revealing not only how old you are, but how ordinary, working-class, and unattractive you would be, seen through the (internalized) male gaze of the new "global elite" of rich men and young women documented in Very Important People: Status and Beauty in the Global
Party Circuit (Mears, 2020). This is where we get to a core, commercial selling point and point of difference of this book, as well as the powerful (not so secret) weapon of its academic research methodology; the author Ashley Mears is not only a successful academic, but a former fashion model who is invited into the inner workings of the murky, man's world of nightlife impresarios and thus can provide an "insider" perspective on this closed, youth (sub)culture.

As Mears (2020, p. 247) herself points out, she uses her own "bodily capital" to solve the research access problem known as "studying up." To put it simply, Ashley is already "up" in the eyes of the male nightlife power brokers and wealthy whales because she is able to "pass" as a fashion model and thus can study her subjects at close range in the clubs, while simultaneously tapping sociological observations and field notes into her smartphone. Mears is doing important and timely work in the 
field of sociology, by laying bare the precarious "working" lives of millennials, as she traces the exploits of nightlife or party players in an influential social milieu which would presumably be invisible or closed to less attractive or less well-connected ethnographers.

Offering an educated but insider commentary on such interesting or "juicy" content as the lifestyles of the heteropatriarchal super-rich, and those who feed off them, this book is almost certain to attract more media attention and popular success. From a more critical, feminist standpoint, however, the strength of the book could also suggest a weakness. So immersed is Mears at times in this culture, so understanding and sympathetic the portrayals of its male players, you do wonder at times if she has drunk the Cristal Kool-Aid. Moreover, the book would have benefited from more critical and feminist informed analysis of how these moonlighting female fashion model "elites" might be empowered and entrapped at the same time-especially in the context of this \#MeToo historical moment and in light of recent revelations of sexual misconduct and ritual humiliation of models in the fashion industry. It would have been interesting to explore more the risks of betting on beauty capital in the culture industries-especially in light of how predatory and abusive these industries can apparently be for some.

\section{Gangster Capitalism: Whales or Sharks?}

I am happy to admit, as a reader with an interest in gender studies, I couldn't put this book down; but that was mostly because I was waiting for the author to critically deconstruct the identity narratives and justifications of some of the fashion models-and the nightclub promoters who apparently recruit and use them. I will also admit I wanted to see her more enthusiastically "harpoon" the billionaire whales, who seemed to me not much more complicated than the entitled, judgmental, middle-aged, ruling class men who you might actually expect to rise to the top of the real estate or finance industries in these ruthlessly competitive, deregulated, neoliberal times. Spoiler alert: this doesn't happen in the end. In fact, I was left with the impression Mears had much less research access to the true, big, swinging power-brokers of this status hierarchy than she might have liked.

We receive comparatively more access to the apparently lower-ranking, more multicultural males of this shadowy scene, the nightclub promoters, who are perhaps mere whale wannabes, but hardly members of the ruling "elite." The apparent protestation of the fashion models, that what they do (essentially selling their appearance to rich, older men in exchange for gifts and luxury experiences) is new and has nothing in common with the work of high class "call girls," doesn't always ring true-in fact, it sounded like yet another way privileged "beauty elite" types may rank and judge other women, through the lens of internalized misogyny. Also, it is still not clear how this new gendered nightlife economy is so different from the traditional strip club wherein men may bond and network while gazing upon the bodies of young women (for a price). Presumably, the glamourous fashion model types would make the distinction that strippers are lower status, lower-class females on the body capital circuit-and this would be of course yet another class-based assumption about taste and style which deserved further critical interrogation.

\section{Hustle Culture: Leisure as Work}

Some of the scenes from this book reminded me of the 2019 Hollywood film Hustlers. Almost all the VIP players in this book, from the "girls" to the nightclub promoters, come across as entrepreneurial "hustlers" trying rather desperately to make it in a ruthless, deregulated, hyper-competitive "hustle" economy of advanced capitalism. You could argue, of course, that the young people described here are just trying their best to make it in hard times, or secure some upward social mobility, in an inherently unequal and unfair system, by any shady means necessary. Feminists should be warned, however, that some of the scenes described in this book will leave you feeling enraged at the blatant sexism and classism on this "elite" party circuit, which is really only "global" in the sense that it is obviously facilitated by global finance and the unfettered mobility of wealthy men and their money.

Moreover, if these players are really so powerful and "elite" why, well may you ask, are they so manifestly desperate to be seen, to be recognized as worthy, that they must pay for it by purchasing luxury experiences of social positioning-and how is this different from what lonely people have always done? This supposedly glamourous and exciting nightlife economy is also rife with old-fashioned misogyny (including internalized misogyny) as Mears (2020, p. 23) relays: "To describe a club that was perceived as lower quality, one promoter flatly stated: 'The girls were fat.' "' Mears freely observes that fashion models are at the top of this hierarchy of female bodies, while women who do not meet the criteria of male clients and promoters are not only denied entry but dismissed as "worthless and contaminating." Moreover, Mears (2020, p. 147) observes: "Part of the fun is getting to join a world that excludes and devalues others."

At the risk of sounding like a sore loser in the beauty stakes, I have to say that standing around in high heels all night, at the behest of wealthy, middle-aged strangers, holding out hope for a free dinner or a luxury handbag, doesn't actually sound very glamourous or fun to me. Surely these well-educated and empowered young women, of the so-called millennial generation, value themselves more highly-or perhaps they are only making the best of the fewer financial opportunities available to them than previous generations, pursuing (post)modern, postfeminist, neoliberal fantasies of easy money and fast upward mobility. If permitted an 
autoethnographic note of my own, I will add that as a young woman I too, went out nightclubbing two to three nights a week (albeit in a far-flung working-class town of regional Australia, not in the world's financial capital) and routinely received free entry, free drinks, and free meals-but we were there to dance and romance other working-class people, not to facilitate, the illusion of, performative wealth and upward social mobility.

I suspect what has occurred since is a generational, as well as socio-cultural, shift around young people and youth culture wherein leisure is remade as work and social life becomes increasingly transactional as part of a growing "hustle" economy. Hence, what I found most fascinating about this important book was what it reveals indirectly about the collective cultural anxieties of the millennial generation; the fear of being overlooked, not important or invisible, against a wider cultural backdrop of cold, hard competition, and individualism. No one in this sexualized, status-obsessed business (think more "hunger games" than "global party") appears "innocent," but it is a cultural trend which academics, parents, and teachers, should certainly be reading and talking about.

\section{Millennial Media Landscape}

What is really new about this material is also what makes it characteristically millennial: The intersections of (micro)celebrity, performative identity construction, and the new networking and communication technologies of social media that grease the wheels of this global party economy. Mears makes little mention, however, of the wider generational shifts or millennial media landscape, despite explaining how Facebook is used in her own research methodology to make the right connections.

The book would have benefited from further discussion of how internet examples of do-it-yourself celebrity or micro-celebrity have facilitated and obviously fed into this narcissistic cultural obsession with being seen, and seen with, the "right" people, via internet-enabled mobile communication technologies. Paris Hilton gets a passing mention as a "pioneer in paid club appearances who created her own celebrity through the VIP scene" (Mears, 2020, p. 25), although I would have liked more exploration of how celebrity paid appearances intersect with the global elite party scene, how social media is integral to this party scene and also some recognition of how and why monetizing this kind of leisure as work is more difficult than it first appears for most young women.

Taking the wider view, we might also note that academia too, is after all, an increasingly competitive "hustle" culture, wherein academics must not only publish, but stand out and be "seen" and self-promote through (new) media to survive-and wherein young people must be attracted, recruited, and absorbed into the ever-growing information economy by (corporatized and marketized) institutions. I would have liked to see more critical commentary on this broader gendered political landscape of "hustle" neoliberalism in the Mears book. Feminism as a theoretical framework is surprisingly absent from most of this book, which is essentially about young women turning their beauty into a commodity to be traded on the nightlife and party scene. Instead of building on feminist works, Mears seems to rely most heavily on the seminal work of the French sociologist Bourdieu, especially his most influential work on distinction and judgments of taste, which was published in the 1970s and the 1980s. But if we are going right back to the 1970s era, it would have been very interesting to connect with the classic British post-war sociology and ethnography of youth cultures captured in classic works like Resistance Through Rituals, if only to demonstrate just how much youth culture-and the academic engagement with it-has changed so dramatically over the past 50 years. Certainly, the romantic youth culture as resistance thesis is completely overturned by the rather ruthless, sell-out culture Mears lovingly and thoroughly documents - there is no place for romanticism of any kind, it seems, among the global party people and those who follow them.

If, like me, you have spent your working life teaching and supporting working class and marginalised young people, it is hard not to feel a little depressed by the stratified, ruthless world of "Very Important People" and even a little lost nostalgia for the naïve optimism of youth and the old-school youth studies of previous generations. The Mears book is one long, hard look at a contemporary youth subculture of young women and men who are not resisting or speaking back to power, but rather strategically playing up to it, in exchange for a (temporary) status bump thrill and other luxury experiences.

This is an important, well-researched book that deserves its popular and academic success - I can't say, however, it left me feeling very optimistic. It made me feel almost sad for these tall, thin, beautiful young women who are apparently so desperate to be seen as somebody important (VIPs), that they will waste their youth hanging around a bunch of entitled, middle-aged bankers and stockbrokers-and even sadder for the "fat" friends who are apparently humiliated and dumped outside the exclusive club. As a Generation Xer it made me want to listen to Nirvana or The Smiths, reflect on progress, or the lack of it, and perhaps just have a good cry-cry even for the beautiful people, trapped in their gilded cages.

\section{Conflict of Interests}

The author declares no conflict of interests.

\section{References}

Mears, A. (2020). Very important people: Status and beauty in the global party circuit. Princeton University Press. 


\section{About the Author}

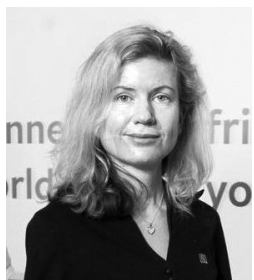

Susan Hopkins is an associate professor of communications based in USQ College at the University of Southern Queensland, Springfield campus, Australia. Susan holds a PhD in social science and a MA (Research) in education. Susan teaches tertiary preparation students, including incarcerated students, and her research interests include media studies, enabling education, and corrections education. 